\title{
PROPERTY DEVELOPMENT RISK ANALYSIS MANDALIKA RESORT LOMBOK TOURISM AREA
}

\author{
I Wayan Muka \\ Departement of Civil Engineering, Faculty of Engineering, University of Hindu Indonesia Denpasar \\ Email: muka_dwiyanjaya@yahoo.com
}

\begin{abstract}
The role of the property sector to the national economy is very important. Not only its role in absorbing labor but also contributions to improving national economic growth. Great relevance to other sectors of the economy also makes the property sector requires strict protection and supervision of various parties, especially the government. It aims to prevent systemic risk due to the fall of the property sector to other economic sectors. Risks and uncertainties always occur in property development. The risk of an effect on every stage of the process of the development of ideas, feasibility studies, commitment to the construction and operation phase. The risk management process is generally a continuous and iterative process, even every kind of development is different and unique properties. This study aims to identify sources of risk, risk factors, the level of hazard, vulnerability level, the level of capacity and determine the priority risks in property development process.

Steps being taken in this study include: the identification of sources of risk, the stage of identification of risk factors, the stage of identification of the level of hazard, the stage of identification of the level of vulnerability, the stage of identification of the level of capacity, the stage of risk analysis and risk priority index ( IPR). Conceptually, the proposed method in this study refers to the key measures of risk management that includes identification, qualitative risk analysis in the process of property development. Data collected through interviews and questionnaires by resource persons involved in property development in the tourism area Mandalika Resort Lombok in West Nusa Tenggara Province.

Results of research on the development of the area Mandalika Resort Lombok can be concluded that the stages of development that are most at risk is the stage of an idea (IPR $=0.152)$, followed by the stage of feasibility (IPR $=0.067$ ), then the commitment stage (IPR $=0,036)$, construction (IPR $=0.026)$ and stage management (IPR $=0.010)$. The results of this assessment indicate that the idea stage is the stage of development of the property are recommended to get treatment or priority risk response. Concluded the process of property development in the region Mandalika Resort Lombok is not worth continuing before risk mitigation that is unacceptable.
\end{abstract}

Keywords: Property Development, Risk Analysis

\section{INTRODUCTION}

Property development is one of the most dynamic businesses, risky and challenging. However, property development has a bad reputation in managing risks. Businesses in the property, as well as with businesses in all other economic areas, it is necessary to manage any risks they face so that a balanced relationship between rentabiltas (rate of return) and liquidity of its business is not disrupted by events, both economic and non-economic, which occurred outside the business. The more successful entrepreneurs to mitigate the risk of the more interested he is to invest their capital, and vice versa. The ability to manage this risk also depends on the extent of risk, both in economic and non-economic it faces in the environment is concerned. The smaller this environmental risk, the smaller the threat that needs to be managed so that it will increasingly attracted entrepreneurs to invest their capital and expand its business, and vice versa. Estimating the risk ofinvestment in the property sector faced in different countries. RREEF is a division of asset management (asset management) Deutsche Bank AG are managing the business management of investment property (real estate) with headquarters in Frankfurt Germany and branches in various countries in the world have a lot of reviewing one company risk estimates. Method of estimation of RREEF took into account, among others; macro economic conditions, political stability, the level of transparency, the legislation, the quality of tenants (tenancy risk), and liquidity of the company concerned. By using a scale from 0 to 5 , RREEF this gives the average number of average of 3.0 to 3.7 for the global and Asia. The risk level of a few cities in Asia in the context of the global average and Asia is shown in Table-1. Table- 1 shows that there are no cities with the risk level below the global average, while those below the Asian average but above the global average is Hong Kong, Singapore, and Tokyo.

Table-1 Risk Level Property Enterprises Cities in Asia (Asia’s New Real Estate Investment Trus,2007)

\begin{tabular}{|l|c|}
\hline \multicolumn{1}{|c|}{ City } & Risk Level \\
\hline Global Average & 3,0 \\
\hline Asia Average & 3,7 \\
\hline Hong Kong & 3,1 \\
\hline Singapore & 3,4 \\
\hline Bangkok & 4,1 \\
\hline Kuala Lumpur & 3,8 \\
\hline New Delhi & 4,2 \\
\hline Seoul & 3,7 \\
\hline Tokyo & 3,3 \\
\hline
\end{tabular}

Enterprise organization's ability to manage risk is highly dependent on the factor of the company and the characteristics of the project and should take into account vulnerability (vulnerability) for risk identification and assessment. In the property development process need to refer to the opinion. Ezell et al (2000) and Sarewitz et al. (2003) which states that the vulnerability is characteristic of a system that would create the possibility of the influence of damage, danger, and failure. Dikmen et al. (2006) reported vulnerability is a system that serves as the control and management (controllability/manageability). While Zhang (2007) states that the vulnerability as the vulnerability of the project (project vulnerability) which is the level or the capacity of the system to respond or cope 
with risk events. Risk is a function of the values of threats, consequences, and vulnerabilities. The objective of risk management is to create a level of protection that alleviate vulnerability to threats and potential consequences, thus reducing the risk to an acceptable level. The implementation of risk management should be an integral part of the implementation of the enterprise management system. The risk management process is one step that can be done to create continuous improvement. The risk management process is also often associated with decision-making processes within a company. This process can be applied in all activities, position, project, product or asset.

Observing the property industry business cycle trip in Indonesia from year to year, indeed experienced ups and downs. In the era of the 1980s, the property business had reached the peak (boom), then in 1983 fell in the lowest point, and in 1986 affected by the oil crisis. Subsequently in 1989, the property sector back to its heyday. Unfortunately, the condition did not last long because in 1993 re-dropped. Business property returned to find the position of a peak in 1997, before the economic crisis hit Asia. Once the crisis hit, the property sector plummeted to the lowest level. Gradually, the real estate business began to rise in 2000, reaching a peak in 2007.

Based on the above it can be concluded that the property business in Indonesia is still experiencing many obstacles and problems, so the need to integrate risk management process in property development. In this study, the risk management process will be applied to the development of properties in the region Mandalika Resort Lombok Tourism. Expected results of this research could overcome the lack of understanding and solutions regarding the implementation of risk management, especially property development in Indonesia.

\section{LITERATURE REVIEW}

The property is defined as "land and all improvement made both on and to land" means land wi th all the repairs, or land and all the objects that are attached on top of it (the building) and fused to it (Simanungkalit, 1996) in Armaini (2006). Property is something that is owned, which is something that can be possessed or anything that can be made the object of ownership. While the notion of the Real Property is is the interest, benefits and rights inherent in the ownership of real estate, which means the interest, profits and rights relating to ownership of land and buildings as well as improvements that are attached to it (Rafitas, 2005). Property development model (Peiser and Frej, 2003) consists of five (5) stages. Figure-1 shows the property development process Peiser and Frej (2003).

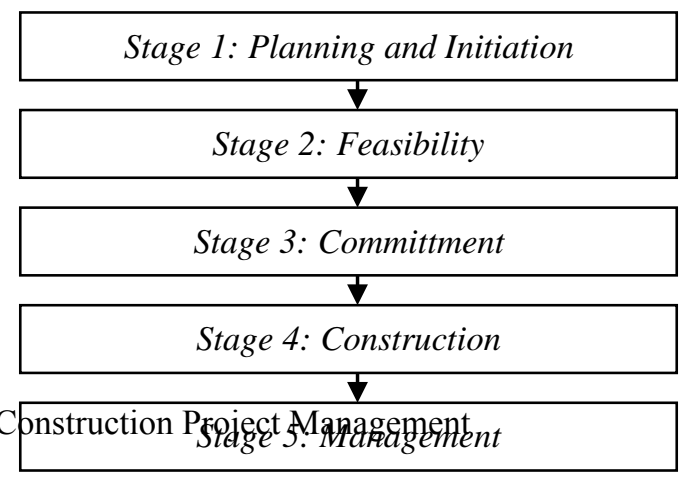

Figure-1. Property Development Model (Peiser and Frej, 2003)

1) The first stage: Planning and Initiation. At this stage begins with the preparation of project administration as a draft preliminary design, site selection, see market opportunities.

2) The second stage: Feasibility .

Conducted a study of market opportunities, feasibility of project financing, planning adapted to the regulations of the local authorities.

3) The third stage: Commitment .

Apply for building permits, land acquisition, marketing

4) The fourth stage: Construction.

At this stage begins with the tender the construction work with a partner or contractor, start of construction jobs, control the cost, quality and time.

5) The fifth stage: Management. At this stage, property marketing, penjualaan and asset maintenance.Aspects of property development are some things that will be evaluated in a reciprocal relationship at any time of the investment decision. Every aspect of the development consists of the preparation of the transaction on the market activities, transactions, and activities to control the consequences of the transaction.

Aspects of development can be divided into (Gehner, 2008):

1) Land Development: all activities concerning the preparation and control of land acquisition and land ready to build, including site selection, land ownership investigation, bought the land and site preparation for building.

2) Design: all activities concerning the preparation and control of the realization of designs, including the initial idea, the concept of the first spatial, physical feasibility studies, the selection of architects, consultants (engineers, landscape architects), design management process.

3) Entitlement: all activities concerning the maintenance of all licenses.

4) Financing: all activities concerning the investment fund.

5) Construction: all activities concerning the physical realization of the project, tendering and contracting, construction supervision, and control of planning and costs.

6) Leasing: all activities concerning the marketing of property projects, including market analysis, feasibility studies, promotional activities and lease agreements.

7) Sales : all activities concerning sales of property projects, including market analysis, valuation, promotional activities, closed sales contracts and property management.

Activities related to every aspect of development can not be done simultaneously for each phase, activity interact in some cases depending on the time. Interaction means that a single activity can be carried out simultaneously in several stages in the development process and some are different for each stage or phase. Second, the process is interactive in the sense that the 
values of certain variables in this process is conditioned by the values of certain other variables (Gehner, 2008), in other words the result of an activity affects the activity of the other. Time dependence implies that the activity must be completed before another can begin.

Table-2. Activity in the Process Aspects of Property Development (Gehner, 2008)

\begin{tabular}{|c|c|c|c|c|c|}
\hline $\begin{array}{c}\text { Fase } \\
\text { Activity }\end{array}$ & Initation & Feasibility & Commitment & Construction & Management \\
\hline $\begin{array}{c}\text { Land } \\
\text { Development }\end{array}$ & $\begin{array}{l}\text { Site selection, } \\
\text { investigation of } \\
\text { land ownership }\end{array}$ & Soil Investigation & Land Purchase & Site preparation & \\
\hline Design & $\begin{array}{l}\text { Development of } \\
\text { idea, spatial } \\
\text { concept }\end{array}$ & $\begin{array}{c}\text { Development of } \\
\text { PoR and } \\
\text { preliminary design, } \\
\text { selection of } \\
\text { architect }\end{array}$ & $\begin{array}{c}\text { Development of final } \\
\text { design and } \\
\text { engineering }\end{array}$ & & \\
\hline Entitlement & $\begin{array}{c}\text { Investigation of } \\
\text { zoning plan and } \\
\text { necessary permits }\end{array}$ & $\begin{array}{l}\text { Investigation of } \\
\text { environmental } \\
\quad \text { effects }\end{array}$ & $\begin{array}{l}\text { Aplication of building } \\
\text { permit, } \\
\text { communication with } \\
\text { interest group }\end{array}$ & $\begin{array}{c}\text { Secure necessary } \\
\text { (building) permits, } \\
\text { application usage } \\
\text { permit }\end{array}$ & \\
\hline Financing & $\begin{array}{c}\text { Analysis bay back } \\
\text { of envelope pro } \\
\text { forma }\end{array}$ & $\begin{array}{c}\text { Analysis of } \\
\text { economic } \\
\text { feasibility, } \\
\text { arranging project } \\
\text { financing }\end{array}$ & Controlling budget & Controlling budget & $\begin{array}{c}\text { Closing loan } \\
\text { generating profit }\end{array}$ \\
\hline Construction & & Cost engineering & Selection contractor & $\begin{array}{l}\text { Excecute building } \\
\text { contracts, supervision } \\
\text { of construction }\end{array}$ & $\begin{array}{c}\text { After care } \\
\text { facility/technical } \\
\text { management }\end{array}$ \\
\hline Leasing & $\begin{array}{c}\text { Watching market } \\
\text { trens, } \\
\text { determining, } \\
\text { target market }\end{array}$ & $\begin{array}{l}\text { Market analysis, } \\
\text { market feasibility } \\
\text { study }\end{array}$ & $\begin{array}{l}\text { Marketing plan, } \\
\text { closing pre rental } \\
\text { agreement }\end{array}$ & $\begin{array}{l}\text { Marketing and } \\
\text { promotion, closing pre } \\
\text { rental agreement }\end{array}$ & $\begin{array}{l}\text { Closing rental } \\
\text { agreements }\end{array}$ \\
\hline Sale & $\begin{array}{c}\text { Watching } \\
\text { economic trends }\end{array}$ & & & & $\begin{array}{c}\text { Property } \\
\text { management, sale } \\
\text { contract sale of } \\
\text { project }\end{array}$ \\
\hline
\end{tabular}

According to Cooper and Chapman (1987) provide an understanding of the risk of a condition in which there is a possibility of profit or economic or financial loss, damage or physical injury, delay, as a consequence of uncertainty over the implementation of an activity.

According Djojosoedarso (2003) states that a risk arises because of the uncertainty that results in a person's doubts about his ability to extrapolate the results of which will occur in the future. In the context of the project, the PMBOK (2004) provides a definition of risk as a condition or event not sure that if the case will have a positive effect and a negative effect on the project objectives. Kerzner (1998) defines risk as events or factors that the event will increase the likelihood of not achieving the purpose of the project time, cost, and performance. In conjunction with the project, then the risk can be defined as the cumulative impact of uncertainty that negatively impact the project objectives. According Kerzner (1998) also explained that in the context of the project, risk management means systematically identify the type, magnitude, and source of risk for the onset of the project cycle, and then prepare the appropriate response to address these risks. In connection with the project management of property risk management is a very useful tool for project management in support of project management to avoid circumstances that can lead to cost over-runs, delays in achieving the schedule, or can not meet the specified performance. Risk management on the project can provide better control for the foreseeable future and significantly provide opportunities achievement of targets.

\section{RISK ANALYSIS}

The development of the concept of risk according to ISDR (2002) which defines the appropriate risk following Equation 1:

Risk $=$ Hazard $\mathbf{x}$ Vulnerability

Thus, the risk is the interaction with the threat of vulnerabilities. Components of the threat (hazard) in Equation 1 is defined as the probability of threat events that occurred at a certain period of time and vulnerability are exposure-dependent relationship with the capacity as the potential to reduce the impact of threats. Vulnerability reflects the capacity of individuals, groups, social economy to withstand the impact of a hazard. If the capacity is low and even a small threat can cause a system failure (Zhang, 2007). Based on Equation 2.4 that risk is a function of the probability multiplied by the impact $(\mathrm{R}=\mathrm{f}$ [Probability $\mathrm{x}$ Impact]) can be transformed that risk dipengruhi by hazard multiplied by vulnerability (Risk = Hazard $\mathrm{x}$ Vulnerability), while the vulnerability is influenced by Capacity, there by Risk = Hazard $\mathrm{x}$ Vulnerability / Capacity. Risks in property development must be considered and managed at every activity activity. Property development process generally consists of five (5) stage: initiation, feasibility, commitment, construction and management. Each stage has a different activity activity and sensitivity to risk. There needs to be a risk assessment at every stage of the development of the property to determine the risk level of each stage so as to 
assist in the decision making process whether it is feasible or not feasible activities conducted with respect besanya indicator of the level of acceptance of risk in this study is called the index of priority risks (IPR). Business property development is a promising and challenging, so that there is an element of threat, vulnerability, capacity management. Based on the description above can be assumed that the risk of developing the property may be influenced by the level of threat, vulnerability level, and the level of capacity. Thus in this study assumed that the threat is a function of the probability events, and vulnerability and capacity is a function of the impact it is assumed that the level of threat, vulnerability, and capacity can be explained as follows:

1) Hazard is a condition that has the potential of causing damages to the company caused by the activity of the property development process such as land development activities, design, financing, licensing, construction, marketing and sales. Menururt Thomas (2008) in relation to property development such threat level: high market growth, shifting buying behavior of people to buy property and the opening of a more diverse product diversification in property management.

2) Vulnerability is a vulnerable condition for the company and as weakness in performing activities of property development processes that may be economic vulnerability, environmental, physical, and social relationships. In accordance with the definition of vulnerability, in connection with property development, according to Thomas (2008) vulnerabilities such as: information about the property is not up to the introduction of products, the management company is not professional, the limited amount of human resources that have the capability in property management services and marketing services standard yet.

3) Capacity is the strength or the ability of the company to achieve the goal of reducing the possible risks that will arise with the use of existing resources. According to Thomas (2008) factors including capacity in property development.

\section{RANKING PRIORITY RISK}

Determination of the risk level of priority do the following stages: assessment of the threat level, the level of vulnerability assessment, assessment of the level of ability, interest level assessment criteria for the purpose of the parties, and the calculation of IPR (risk priority index).

1) The interest rate criterion

Based on the existing problems, the structure of the criteria as well as alternative can be arranged in a hierarchical system. Related to this thinking, the events. In this study to measure the risk of property development analyzed by Equation 2 as follows:

$$
\text { Rpi }=\frac{\text { Hpi x Vpi }}{\text { Cpi }}
$$

Where:

Rpi = Risk in Property Development

Hpi $=$ Threat in property development

Vpi $=$ Vulnerability in property development

Cpi $=$ The capacity in property development

In the context of this study

Analytical Hierarchy Process chosen as the appropriate method to determine the level of interest.

2) Assessment of Risk Priority Index (IPR)

Assessment of risk priority index (IPR) can be performed after the weight of importance criteria for the purpose of the parties is obtained. Calculation of risk priority index (IPR) is the result of the analysis of the weight of importance of each level and the value of risk based on the level of threats, vulnerabilities and capacity levels. Assessment of risk levels of priority starting with the assessment of the level of threat, vulnerability level, the level of capacity and takes into consideration the interests of the relative weight of the criteria specified.

IPR is calculated using the formula (Brojonegoro, 2004) in accordance with Equation 3 as follows:

IPR = A (A1 x value risk a1 +... A6 x value risk a6 + $\ldots . .+\mathrm{D}$ (D1 $\mathrm{x}$ weight $\mathrm{d} 1+\ldots+$ D5 $x$ risk value $\mathrm{d} 5$

IPR = Risk Priority Index; A-D = Weight of Alternative Level 2 (based on analysis of respondents); A1, A2, ... .D5 $=$ Weight of Alternative Level 3 (based on analysis of respondents); risk values a1, a2 risk value, ...., the value of risk $\mathrm{d} 5=$ Value risk

\section{RESEARCH RESULT}

Risk analysis begins with identifying sources of risk, identifying the level of threat, identify the vulnerability, identifying the level of capacity and prioritize risks. The risk value is calculated as follows: for example, a resource assessment \# 1 at the idea stage to the risk of site selection and land ownership (A1) as follows:

Hazard1(H1)=3, Vulnerability1(V1) = 3, Capacity1(C1) = 3, Risk1(R1) = $3 \times(3 / 3)=3.00$; normalized 3/25 = 0.12

Hazard2 $(\mathrm{H} 2)=4$, Vulnerability2 (V2) = 4, Capacity2 $(\mathrm{C} 2)=3$, Risk2(R2) $=4 \times(4 / 3)=5.33$; normalized 5.33 / $25=0.21$

The average value of risk $\mathrm{A} 1=(\mathrm{R} 1+\mathrm{R} 2) / 2=(0.12+$ 0.21 ) $/ 2=0.167$

Recapitulation Mandalika Resort value of the risk areas in accordance with Table-3

\begin{tabular}{|c|c|c|c|c|c|c|c|c|}
\hline \multirow[t]{2}{*}{ No. } & \multirow[t]{2}{*}{ Stage } & \multirow{2}{*}{$\begin{array}{l}\text { Risk Sources } \\
\text { (SR) }\end{array}$} & \multicolumn{5}{|c|}{ Resp. } & \multirow{2}{*}{$\begin{array}{l}\text { Risk } \\
\text { Value }\end{array}$} \\
\hline & & & $\mathrm{N} \# 1$ & $\mathrm{~N} \# 2$ & $\mathrm{~N} \# 3$ & $\mathrm{~N} \# 4$ & $\mathrm{~N} \# 5$ & \\
\hline \multirow{5}{*}{$\mathrm{I}$} & \multirow{5}{*}{ INITIATION } & $\begin{array}{l}\text { A1. The risk of site selection and land } \\
\text { ownership }\end{array}$ & 0,167 & 0,167 & 0,100 & 0,213 & 0,180 & 0,165 \\
\hline & & A2. Preliminary design risk & 0,125 & 0,135 & 0,053 & 0,160 & 0,160 & 0,127 \\
\hline & & $\begin{array}{l}\text { A3. Risk investigation zoning and licensing } \\
\text { process }\end{array}$ & 0,140 & 0,280 & 0,080 & 0,267 & 0,267 & 0,207 \\
\hline & & A4. Interest rate risk and inflation & 0,155 & 0,113 & 0,085 & 0,200 & 0,140 & 0,139 \\
\hline & & A5. The risk of market segments and market & 0,200 & 0,160 & 0,100 & 0,133 & 0,140 & 0,147 \\
\hline
\end{tabular}

Table-3 Risk Value Mandalika Resort Area 
The 2nd International Conference on Civil Engineering Research (ICCER) 2016

"Contribution of Civil Engineering toward Building Sustainable City"

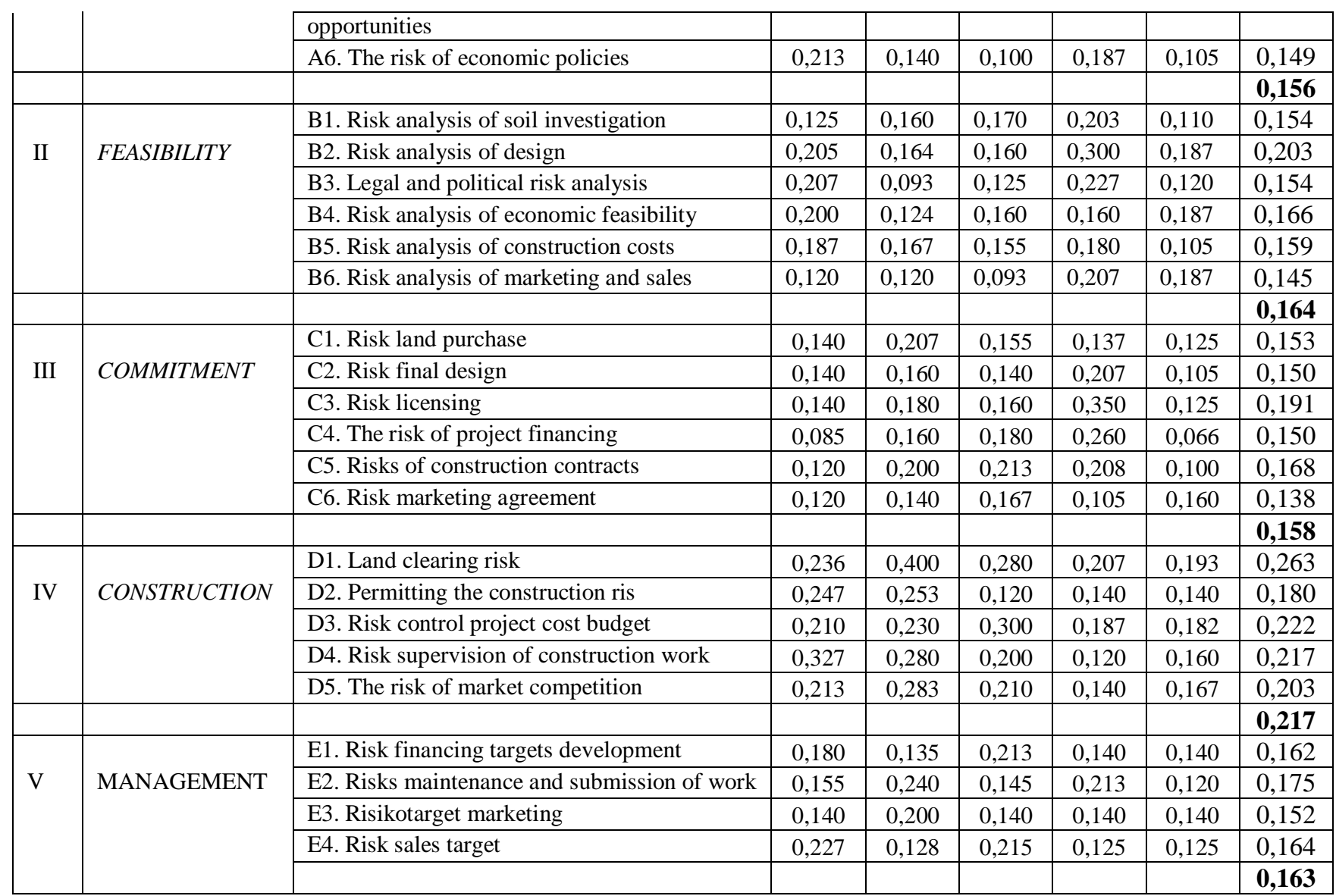

According to Table-3 for Mandalika Resort area of highest risk value is 0.217 construction phase; The next stage of the feasibility of $\quad 0.164 ; \quad 0.163 \quad$ management stage; 0.158 commitment stage; and 0.156 idea stage. The risk priority index Mandalika Resort area according Figure 2 below:

Level I

(goal)

IPR Mandalika Resort 0,291

Level II

(criteria)

Level III

(sub criteria)
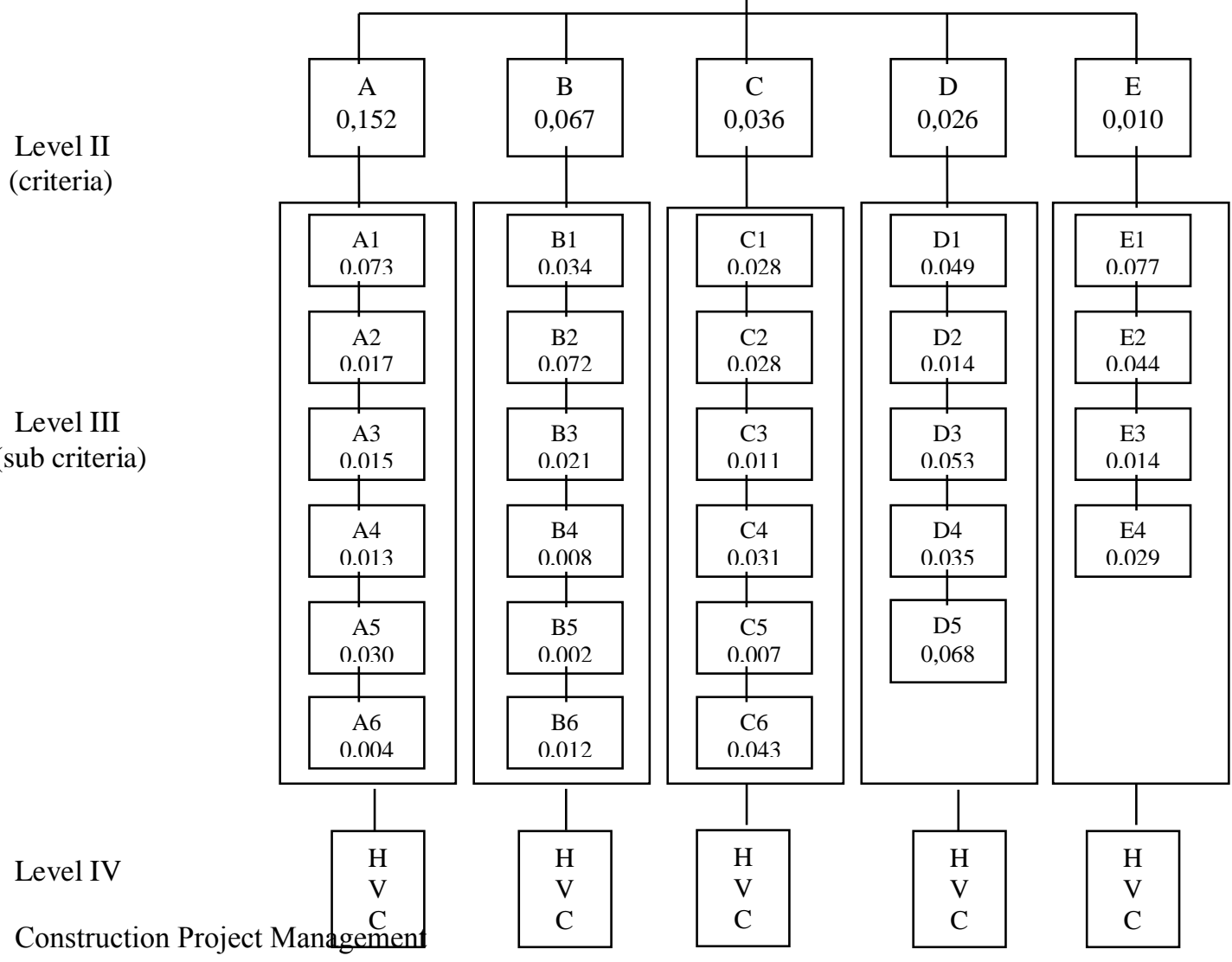
(alternatif)

\section{DISCUSSIONS}

Mandalika Resort Lombok region in accordance with the master plan of the planned selus 1,175 Ha. But in 2011 the land is problematic in Tourism Region Mandalika Resort divided into three groups, namely, land that has not been freed, lands occupied population because the long unfinished, the land is still a lawsuit until 2014 covering an area of 135 hectares. PT. Development of Tourism Indonesia (ITDC) as the company is given the task by the central government to manage the region until the year 2014 has not been able to carry out construction of the reasons investors have committed to invest cancel cooperation and bailouts of government have not been realized. According to the results of surveys and interviews with local community leaders that the region Mandalika Resort construction is still encountered many obstacles and problems include land acquisition, ownership, investors to invest is low, the financial support from the central government have stalled. Based on the value of risk as in the area of Nusa Dua Resort indicates that the level of threats, vulnerabilities and capacities in the region Mandalika Resort shows the low category. However, after the value of the risk and the weight of the parties analyzed the level of interest was shown that the region as a whole Mandalika Resort (Level I) has a 0.29 IPR, IPR stage with the idea of 0.152; IPR feasibility phase of 0,067 ; IPR commitment phase of 0,036 ; IPR construction phase of 0.026 ; IPR management phase amounted to 0,010 . Risk factors which receive priority handling and continuous monitoring are: the risk of site selection and land ownership, risk analysis of design, marketing agreements risk, the risk of the project budget cost control and risk financing for development targets. By IPR of 0.291 means that the overall level of risk of development of the area Mandalika Resort unacceptable (IPR> 0.24) and the development of the area Mandalika Resort has not been feasible to be developed or constructed. So as to be able to implement the development of identified priority risk areas should receive treatment (mitigation) and to gain control of the risk priority index (IPR) in the category of risk is acceptable.

\section{CONCLUSION}

Sources of risk consists of 7 (seven) sources, namely; land development, design, financing, entitlement, construction, and management. Further risk factors are identified, the level of hazard, vulnerability, capacity at any stage of development properties. Property development process that involves a lot of resources and lasted for a long time and requires a risk-sensitive risk management practices in a systematic and responsible. Risk management in property development process in a systematic and responsible may be assisted by the risk management model. Risk management model in this study can be applied to property management projects to help stakeholders make the decision to invest in property. This

\section{x Mandalika Resort Area}

model can provide a decision to the parties, especially developers whether the activity can be continued or not ketahap next. So the loss especially in the management of the property can be anticipated early start from the idea stage initiation, feasibility, commitment, construction, and management.

\section{REFERENCES}

Armaini (2006), Quantitative risk analysis of real estate investments in the city of Denpasar. Thesis Masters Degree in Civil Engineering University of Udayana.

Brodjonegoro, PS, 1991. The Analytic Hierarchy Process and Risk ethod. Jakarta: SaptaUtama

Cooper, DF, DH Macdonald and Chapman, CB 1987. Risk Analysis for Large Project, John Wiley \& Sons Ltd., Norwich.

Dikmen, I, Birgonul, T. 2006. An analytical process-based models for risk opportunity assessment of international construction projects, Canadian Journal of Civil Engineering.

Djojosoedarsono, S. 2003. Principles of Risk Management and Insurance, Salemba Four, Jakarta

Ezell, B., Farr, J.and Wiese, I. 2000. Infrastructure risk analysis models, Journal of Infrastructure sytem, 6 (3), 114-117

ISDR. 2002. Words into Action:aguide for implementing the Hyogo Framework

Gehner et al. 2006. Risk management in the Dutch real estate development sector: a survey ", Proceedings of the 6th International postgraduate research conference in the built and human environment. University of Salford, UK.

Kerzner, H. Management of Project 1998: A Systems Approach to a Planning, Scedulling and controlling. 6thed.

Peiser, R.B. and Frej, AB 2003. Professional Real Estate Development.The ULI Guide to the Business, Washington D.C.

Rafitas, AB 2005. Kiat Sukses Bisnis Broker Properti. Bumi Aksara, Jakarta

Sarewitz, D., Pielke, Jr.R.and Keykhah, M. 2003.Vulnerability and risk: Some thoughts from a political and policy perspective. Risk Analysis, 23 (4), 805-10

Thomas.A.2008.Property management businesses in entering the market: A case study on PT. Petrimeq. Tesis.Universitas Indonesia

Zhang, H. 2007. A redefinition of the project risk process: using vulnerability to open up the event concequence link ", International Journal of Project Management. 